\title{
How Plausible the Predicted Superiority of Private Over Public Investment Still Stands, If Ever?
}

\author{
Benjamin García Páez ${ }^{1}$ \\ ${ }^{1}$ Faculty of Economics, National University of Mexico (UNAM), Mexico City, Mexico \\ Correspondence: Benjamin Garcia Páez, National University of Mexico (UNAM), Economics Department \\ Annex building $2^{\text {nd }}$ floor, Mexico City, Mexico. Tel: 525-518-384-986. E-mail: garpaez@ unam.mx
}

Received: July 29, 2021

Accepted: August 26, 2021

Online Published: September 5, 2021

doi:10.5539/ijef.v13n10p87

URL: https://doi.org/10.5539/ijef.v13n10p87

\begin{abstract}
This essay aims to test the hypothesis held by the Theory of Financial Liberalisation in the sense that financial resources diverted by non-market forces are inefficiently allocated, ergo, public investment is less productive than private investment. The relationship between public and private investment and the productivity in both the public and the private sectors are then analysed in search of empirical evidence to discern the endurance of such hypothesis throughout the changing evolution of theMexican financial system since 1970 up to 2019. The paper is arranged in four sections. Firstly, some historical financial liberalisation events are put forward. Secondly, theoretical issues concerning the concept of productivity of the two types of investment are discussed. It also reviews empirical work done on the productivity in less-developed countries. Thirdly, an attempt to measure productivity of both public and private investment in Mexico is made. It then describes the methodology and the estimation results obtained for Mexico are launched. Finally, main conclusions are delivered.
\end{abstract}

Keywords: Mexican economy, investment and economic growth, productivity of investment, public and private investment, financial liberalisation models

\section{Introduction}

In Mexico, the public investment played a leading role in promoting economic growth particularly during the 1970s, given that the rate of growth of public investment was higher, on average, than that of private investment. By the late 1980s, however, the relative importance of the public investment was beginning to wane. The declining and the correlative ascent of private investment obey to an unfortunate conjunction of circumstances such as the running of huge budget deficit, balance-of-payment disequilibrium, growing external debt, slumping barrel of oilprice, domestic political turmoil and, above all, the ensuing fiery debate against the alleged congenital deficiency of governmental intervention in the economy which legitimate market take over public assets.

All these events veered off the economic growth model and the development strategy from one long-pursued state led to the current market-led biding whereby the private sector is the leading protagonist. Amid such deepen structural reforms prompted, the financial reform constitutes an eloquent example why many legal and operational changes were undertaken, for instance: the autonomy of the Mexican central bank is decreed (1994), and its organic scope was re-functionalised; since then, the foreign financial investment could build financing groups and to acquire financing and non-financial assets, among others.

In as much as one of the seductive hypotheses underlying the transition from the existing repressed financial system up to 1989 year to another liberalised scheme, predicated that the productivity of public investment is lower than investment, this work take on the objective to find out the contribution of both kind of investment in the economic process during a period long enough to compare no only their relative contributions as a such but it compare their performance through productivity investment so to appreciatewhether public investment in lesser productive than private investment in less developed countries became a reality in the case of the Mexican economy.

As the structural financial reform has been elevated to constitutional rank, the changes involved have become almost irreversible. So, it is important to assess the scope of the current financial policy through the testing of a quintessential hypothesis of the theory of financial liberalisation like the one predicting a greater productivity of private investment over public investment public not only because that led to the quasi-foreignization of the 
commercial banking system and the correlative waning of the development banks but also because the abundance of loanable funds and the setting of competitive interest rates promised were not a reality so leaving Mexico lacking of means to finance its development process.

\section{Method}

\subsection{Investment and Economic Growth}

Different arguments gravitate towards the issue of public and private productivity. Wall (1990) discuss two related issues: what is the appropriate mix of public and private investment; and what criteria can be used to ensure that the public investment is efficient. Newlyn (1977) argues that there is no a priori reason to consider public investment les productive than its opposite. The World Bank (1989) postulates that the public or private enterprise's ownership cancause significant differences in the enterprise's performance. Balassa (1988) stresses that some level of public investment is a sine qua non to create the environment and infrastructure necessary to make economic activities of all kinds possible and more efficient. Tanzi (1976) argues that public investment can be considered as a kind of input for private investment and that the productivity of private investment is closely related to both the level and the quality of investment in the public sector. In general, he argues, "apart from investment in public enterprises, the direct contribution of most public investment to potential output is not high. It is generally its effect on the productivity of private investment that makes public investment worthwhile" (p. 11).

By contrary, Collier and Mayer (1989) stated that the economy would gain by liberalising its financial sector since "in the presence of financialrepression, the government expands its control over resources which would otherwise be allocated by the market. The government allocatesresources to investment, but the selection is poor" (p. 7). Ize (1989) point out that privatisation of industries is one of the measures recommended by the World Bank and the IMF to countries wanting to rise the overall efficiency of investment.

Khan and Reinhart (1990) test the relationship between public and private investment and economic growth in developing countries, to determine, based on empirical evidence, if policies to encourage private at the expense of public investment will help the growth rate.The authors formulate a growth model that subdivide the effects of public and private investment. The model is based on an aggregate production function where output (y) depends on the stock of capital (K), the labour force L, "other variables" affecting growth $(\mathrm{Z})$ and total factor productivity $(\alpha)$ :

$$
y=\alpha f(K, L, Z)
$$

Expressing (1) in growth terms:

$$
\frac{\partial}{y}=\left[\alpha \frac{\partial y}{\partial k}\right] \frac{\partial k}{\partial y}+\left[\alpha \frac{\partial y}{\partial L} \frac{L}{y}\right] \frac{\partial L}{L}+\left[\alpha \frac{\partial y}{\partial z} \frac{z}{y}\right] \frac{\partial Z}{Z}+\frac{\partial \alpha}{\alpha}
$$

Writing (2) for estimation purposes as:

$$
\frac{\Delta y}{y_{t-1}}=\alpha_{0}+\alpha_{1} \frac{I}{y_{t-1}}+\alpha_{2} \frac{\Delta L}{\mathrm{~L}_{\mathrm{t}-1}} \alpha_{3} \frac{\Delta Z}{\mathrm{z}_{\mathrm{t}-1}}
$$

where:

$$
\alpha_{0}=\frac{\partial \alpha}{\alpha} ; \alpha_{1}=\frac{\partial y}{K} ; \alpha_{2}=\frac{\partial y}{\partial L} \frac{L}{y} ; \alpha_{2}=\frac{\partial y}{\partial Z} \frac{Z}{y} ; I=\partial K
$$

The constant term $\alpha_{0}$ is assumed to capture the growth in productivity, $\alpha_{1}$ is the marginal productivity of capital; $\alpha_{2}$ is the elasticity of output with respect to labour and $\alpha_{3}$ is the elasticity with respect to other variables affecting growth. Considering the productivity of capital calculation, the authors specify that the Incremental-Output Capital Ratio, ICOR (Note 1), can be estimated from the equation expressed in (4) if $\alpha_{0=} \alpha_{2=} \alpha_{3}=0$. In this case, $1 / \alpha_{1}$ would be the estimated actual ICOR. However, when this simple equation is applied in the empirical analysis of growth of less developed countries and the parameters estimated show that $\alpha_{0} \neq 0, \alpha_{2} \neq 0, \alpha_{3} \neq 0$, the coefficient $1 / \alpha_{1}$ would be the net ICOR, which estimates the partial effect of investment on output when the other variables ( $\mathrm{L}$ and $\mathrm{Z}$ ) in equation (1) remain constant.

To test the differential effects of public and private investment on the growth rate, total investment is then divided into public $\left(I_{p b l)}\right.$ and private nivestment $\left(I_{p r v}\right)$ :

$$
\frac{\Delta y}{\mathrm{y}_{\mathrm{t}-1}}=\beta_{0}+\beta_{1} \frac{I_{p b l}}{y_{t-1}}+\beta_{2} \frac{I_{p r v}}{y_{t-1}}+\beta_{3} \frac{\Delta L}{\mathrm{~L}_{\mathrm{t}-1}}+\beta_{4} \frac{\Delta Z}{\mathrm{Z}_{\mathrm{t}-1}}
$$

The relative values of $\beta_{1}$ and $\beta_{2}$ would indicate either that the respective marginal productivities are equal, when 
$\beta 1=\beta 2$, or that the marginal productivity of public investment is higher than that of private investment, $\beta_{1}>\beta_{2}$, that the marginal productivity of private investment is higher than that ofpublic investment, $\beta_{1}<\beta_{2}$. The authors stress that caution should be taken in interpreting the marginal productivity estimates, since public investment can have indirect effects on private investment, and there is uncertainty about whether these indirect effects are positive or negative.

In specifying "other variables (z)", Khan and Reinhart include the rate ofgrowth of exports (X) and imports (M) as explanatory variables in two separate equations:

$$
\frac{\Delta y}{\mathrm{y}_{\mathrm{t}-1}}=\beta_{0}+\beta_{1} \frac{I_{p b l}}{y_{t-1}}+\beta_{2} \frac{I_{p r v}}{y_{t-1}}+\beta_{3} \frac{\Delta L}{\mathrm{~L}_{\mathrm{t}-1}}+\beta_{4} \frac{\Delta X}{X_{\mathrm{t}-1}}
$$

And:

$$
\frac{\Delta y}{\mathrm{y}_{\mathrm{t}-1}}=\beta_{0}+\beta_{1} \frac{I_{p b l}}{y_{t-1}}+\beta_{2} \frac{I_{p r v}}{y_{t-1}}+\beta_{3} \frac{\Delta L}{\mathrm{~L}_{\mathrm{t}-1}}+\beta_{4} \frac{\Delta M}{M_{t-1}}
$$

The results of estimating these equations for a cross-section of 24 countries, among them Mexico, over the period 1970-1979 period showthat the estimated marginal productivity of private investment has consistently higher statistical significance than that of public investment.Moreover, the estimated marginal productivity of public investment, although not statistically significant, has a negative sign in the two specified equations. The estimated marginal productivity of privateinvestment is between 0.158 and 0.209 with t-statistic higher than 3 in each case, while the estimated marginal productivity of public investment is either equal to (-) 0.108 (with a tstatistic equal to 1.02) when growth of exports is included as an explanatory variable, and equal to (-) 0.182 (t-statistic equal to 1.55) when the rate of growth of imports is included as an explanatory variable.

Public investment is then excluded from the explanatory variables due to its lack of statistical significance, resulting in a rise in the coefficientsand the statistical significance of the private investment ratio. The authors do not report any result where the public investment ratio is included instead of the private investment ratio.

Concerning their results, Khan and Reinhart (1989) argue that "public sector investment in developing countries has no direct effect on growth, which is of course, an important result. Based on these estimates there is a little doubt that the direct effects of private investment on growth outweigh the direct effects of public sector investment" (p. 23).

Sarmad (1990) tests the Khan and Reinhart model and concludes that "the role of public investment in the growth process in developing countries appears to be no less important than that private investment,though the pattern of public investment contribution to growth has changed significantly along time" (p. 10). A possible explanation for the change in the impact of public investment during the past two decades, he argues, is that public investment was used in projects with a long gestation and in many cases unproductive which might have negatively affected the contribution of the public sector to aggregate growth.

\subsection{Productivity}

Even though the meanings of efficiency and productivity are not precisely the same, they are close related (Shone, 1981). Efficiency is concerned with how best to utilise resources in the production process. Efficiency of production is also referred to as the minimisation of unit costs of all factors of production by applying better techniques (Nadiri, 1970). Productivity is concerned with the output to input relation. Aldred (2010, p. 65) points out that "productivity improvements simply refer to changes which enable resources to be used more efficiently... workers may have adopted more efficient working practices, or there may have been some technical innovation which allows material inputs to be used more productively". Shone (1981) refers to efficiency as more all-embracing concept than productivity; he argues that is possible to define them in such a way that they are synonymous, but "this would not be useful because we would soon find that we would require a concept to go beyond productivity as conventionally understood" (p. 125). Nevertheless, he adds, efficiency is not a simple concept, it is far from clear, and it is difficult to measure. Since the interest of this analysis lies in the effect and output growth, however, efficiency will be understood as productivity (Haskel et al., 2020).

At this work, the ICOR is assumed to be a correct yardstick for macroeconomic productivity (Note 2). In this scope, there are three types of ICOR (see Leibenstein, 1966): a) the actual ICOR, which accounts for the ex-post relation between investment and changes in output; b) the net ICOR, which considers the change in output due to a change in other factors of production; and c) the adjusted ICOR, which considers the effects of investment on output growth given specific changes in other factors of production. Thenet and the adjusted ICORs would allow us to isolate the effects of increases in investment on increases in output. When using the actual ICOR, all 
changes in output are attributed to changes in the stock of capital, since changes in other factors of production are not being considered. Hence, its results will be underestimating the ICORs and overestimating the productivity of investment (see Thirlwall, 1989; Warman \& Thirlwall, 1994).

In the macroeconomics of development, productivity is real output per unit of input and distinguishes the following types: the average productivity of capital, which is defined as the output-input ratio for each level of output and the corresponding level of input $(\mathrm{K})$, i.e. $\overline{\mathrm{a}}=\mathrm{Y}(\mathrm{K}) / \mathrm{K}$ and the marginal productivity of capital, which is defined as the addition to total product attributable to the addition in turn of one unit of capital, i.e. $\alpha_{\mathrm{mg}}=\delta \mathrm{Y}(\mathrm{K})$ / $\delta$ K. (Note 3$)$

If $\mathrm{Y}(\mathrm{K})=\alpha+\sigma \mathrm{K}$ and $\alpha \neq 0$, then the marginal productivity differs from the average productivity. The resulting coefficients $\widehat{\sigma}_{i}$ are thus estimates of the marginal productivity of investment, which is independent of the level of input $(\mathrm{K})$. The independence of the estimated productivity from the level of investment is important in this case since the level of public investment is lower than the level of private investment during the period analysed. If $\alpha \neq \alpha^{2}$ might partly reflect a lower average level of public investment compared to the average level of private investment.

To recapitulate, among the few empirical studies trying to find out the relationship between public and private investment on the one hand and economic growth on the other, it stands out that of Khan and Reinhart (1990) who point out that "there is virtually no empirical evidence that can be called on to support or disprove the notion that private investment is in some sense "better" that public investment insofar as long-run growth is concerned" (p. 20).

Perhaps one of the reasons for the scarcity of this kind of study is the difficult of the meaning of the resulting productivity estimates, since public investment, which has and exogenous behaviour, can have positive and/or negative effects on private investment, thus affecting the latter's productivity.

Bearing in mind that the estimation results might be weak, and that careshould be taken in their interpretation, this section proceeds to analyse the methodology and results of calculating the productivity of investment.

Before undertaking the empirical analysis, a pertinent point should be made. As 1989 is the turning point in the shift of the Mexican financial system from being repressed in nature towards a liberalised scheme, the overall period is bifurcated in two sub-periods: 1970-1990 and 1990-2020. As well, this shall allow us to contrast the results to be estimated and make qualitative judgements upon them.

\section{Model Methodology}

Following the Khan and Reinhart's model, the productivity of public andprivate investment in Mexico is estimated by including them as separatevariables of the output function. Considering the level of real output, Y, as a function of capital K:

$$
Y=\sigma K
$$

Where $\sigma$ is the productivity of $\mathrm{K}$ and differentiating (8) with respect to time, we get:

$$
\frac{\delta Y}{\delta_{t}}=\sigma\left(\frac{\delta K}{\delta_{t}}\right)
$$

Expressing (9) for estimation purposes as:

$$
\Delta Y_{t}=\sigma I_{t}
$$

Since $\left(\frac{\delta K}{\delta_{t}}\right)=I$, where $\Delta \mathrm{Y}$ is the change in real output and I is total investment. If we consider, in turn, that the stock of capital $\mathrm{K}$ consists for a public and a private component, then:

$$
\Delta \mathrm{Y}=\sigma\left(\mathrm{I}_{\mathrm{pbl}}+\sigma_{2} \mathrm{I}_{\mathrm{prv}}\right)
$$

Differentiating (11) with respect to time, gives:

$$
\frac{\delta \mathrm{Y}}{\delta_{\mathrm{t}}}=\sigma\left(\frac{\delta \mathrm{K}_{\mathrm{pbl}}}{\delta_{\mathrm{t}}}+\frac{\delta \mathrm{K}_{\mathrm{prv}}}{\delta_{\mathrm{t}}}\right)
$$

Since we are interested in testing the hypothesis of different values of $\sigma$ for private and public capital, then:

$$
\frac{\delta \mathrm{Y}}{\delta_{\mathrm{t}}}=\sigma_{1}\left(\frac{\delta \mathrm{K}_{\mathrm{pbl}}}{\delta_{\mathrm{t}}}+\sigma_{2} \frac{\delta \mathrm{K}_{\mathrm{prv}}}{\delta_{\mathrm{t}}}\right)
$$

Expressing (13) for estimation purposes as: 


$$
\Delta \mathrm{Y}_{\mathrm{t}}=\sigma_{1} \mathrm{I}_{\mathrm{pbl}_{\mathrm{t}}}+\sigma_{2} \mathrm{I}_{\mathrm{pvt}}
$$

Taking the basic equation of Harrod's growth model: $\dot{g}=s \sigma$, where $\dot{\mathrm{g}}$ is the rate of growth of output, $s=$ the propensity to save, and $\sigma=$ the productivity of capital; and considering that in equilibrium savings are equal to investment:

$$
\frac{s}{Y}=\frac{\mathrm{I}}{\mathrm{Y}}=\mathrm{s}
$$

Then, output growth can be expressed as a ratio of investment to output as:

$$
\mathrm{g}_{\mathrm{t}}=\dot{\sigma} \mathrm{I}_{\mathrm{t}} / \mathrm{Y}_{\mathrm{t}}
$$

Considering that the total investment is equal to public plus private investment, then:

$$
\mathrm{g}_{\mathrm{t}}=\sigma_{1}\left(\frac{\mathrm{p}_{\mathrm{pbl}}}{\mathrm{Y}_{\mathrm{t}}}\right)+\sigma_{2}\left(\frac{\mathrm{I}_{\mathrm{pvt}}}{\mathrm{Y}_{\mathrm{t}}}\right)
$$

To compare the estimated equations between total, public and private investment productivity, equations (10), (14), (16) y (17) are estimated by two procedures. Firstly, econometric methods (Ordinary Less Squares-type) are used to estimate the marginal productivity value as the coefficient of investment when using the change in output as a dependent variable [in equations (10) and (14)], or, as the coefficient of investment to output when using the rate of growth of output as the dependent variable [in equations (16) and (17)]. Secondly, the ICOR is calculated on an annual basis, obtaining the average ICOR for each sub-period chosen, and calculating both the average and marginal productivity of investment as the reciprocal of the average ICOR accordingly.

For econometric work, equations (10) (14) (16) and (17), can be rewritten, respectively, as follows:

$$
\dot{g}=\sigma_{0}+\sigma_{2} I_{t}+\varepsilon_{i}
$$

Where $\dot{\mathrm{g}}=$ real growth rate and $\mathrm{I}_{\mathrm{t}}=$ total investment.

$$
\dot{g}=\sigma_{0}+\sigma_{1} I_{t} / Y_{t}+\varepsilon_{i}
$$

Where $I_{t} / Y_{t}$ may apply as public investment as private investment coefficients.

\section{Estimation Results}

All the equations specified in this section include an intercept term in their estimation, thus allowing the average and the marginal productivity to differ (Note 4). Furthermore, a common feature of the tables is that including the dummy variables for 1982, 1983 and 1986 for the first sub-period, and 1995, 2000, 2001 and 2009 for in the second sub-period, i.e., one for each year in which output growth is negative. This procedure improves the statistical reliability as of the statistics tests as the estimated productivity coefficients (Mukherjee, 1998) (Note 5). $\mathrm{R}^{2}$, the DW and the F statistics, the Lagrange Multiplier test of autocorrelation of the errors $\left(\mathrm{SC}_{\mathrm{LM}}\right)$ are reported for both cases and sub-periods.

\subsection{Econometric Results (1970-1990)}

Table 1 shows the results of estimating equations (10) and (14). The estimated coefficients of public, private, and total investment in Table 1, when $\hat{\sigma}=\frac{\Delta Y}{I}$, show the productivity of total investment as a weighted average of the productivity of public and private investment. Thus, a positive estimated of public investment $\left(\widehat{\sigma}_{1}=0.78\right)$ and statistically significant $(t=3.16)$ are obtained, while the estimated productivity of private investment is negative $\left(\widehat{\sigma_{2}}=-0.07\right)$ and not statistically significant $t=-0.28$ (Note 6).

However, taking these results at their face value, they are opposite to those obtained by khan and Reinhart (1990) in the sense that a negative productivity would be conferred, not to the public investment as in their case, but to private investment. 
Table 1. Estimated marginal productivity of total, public and private investment

\begin{tabular}{|c|c|c|c|c|c|c|c|c|c|c|}
\hline \multicolumn{11}{|c|}{ Equations (10) and (11) } \\
\hline \multicolumn{11}{|c|}{$\hat{\mathbf{o}}=\Delta \mathrm{Y} / \mathbf{I}$} \\
\hline $\begin{array}{c}\text { Constant } \\
\text { Term }\end{array}$ & $\begin{array}{c}\text { Total } \\
\text { Investment }\end{array}$ & $\begin{array}{c}\text { Public } \\
\text { Investment }\end{array}$ & $\begin{array}{c}\text { Private } \\
\text { Investment }\end{array}$ & DU82 & DU83 & DU86 & $R^{2}$ & $D W$ & $F$ & $\begin{array}{l}X_{(1)}^{2} \\
\text { SCLM }\end{array}$ \\
\hline 2.36 & - & 0.46 & -0.005 & - & - & - & 0.10 & 1.22 & 1.01 & 3.31 \\
\hline$(0.08)$ & - & $(1.15)$ & $(-0.01)$ & - & - & - & & & & \\
\hline-0.50 & - & 0.78 & -0.07 & -58.3 & -78.7 & -53.9 & 0.93 & 1.46 & 29.40 & - \\
\hline$(-0.02)$ & - & $(3.16)$ & $(-0.28)$ & $(-6.44)$ & $(-8.16)$ & $(-6.57)$ & & & & \\
\hline-6.04 & 0.227 & - & - & - & - & - & 0.08 & 1.19 & 1.64 & 3.58 \\
\hline$(-0.2)$ & $(1.28)$ & - & - & - & - & - & & & & \\
\hline-23.0 & 0.38 & - & - & -55.3 & -76.4 & -49.6 & 0.91 & 1.77 & 28.31 & - \\
\hline$(-1.0)$ & $(2.78)$ & - & - & $(-5.83)$ & $(-7.21)$ & $(-5.94)$ & & & & \\
\hline
\end{tabular}

Note. t-statistics in brackets.

Table 2 shows the estimated ô values for equations (16) and (17) when $\hat{o}=\mathrm{g} /(\mathrm{I} / \mathrm{Y})$. In this case, the constant term is statistically significant in all the estimation reported. The results obtained when the dummy variables are included are interesting since both the coefficients of the public and the private investment ratio have positive and statistically significant values. The estimated productivity of public investment is $0.77(t=3.87)$ and the estimated productivity of private investment is $0.68(\mathrm{t}=1.90)$. The estimated productivity of total investment is a weighted average of public and private investment equal to 0.74 (Note 7).

Table 2. Estimated marginal productivity of total, public and private investment

\begin{tabular}{|c|c|c|c|c|c|c|c|c|c|c|}
\hline \multicolumn{11}{|c|}{$\begin{array}{c}\text { Equations (18) and (19) } \\
\hat{\mathrm{o}}=\mathrm{g} /(\mathbf{I} / \mathbf{Y}) \\
\end{array}$} \\
\hline $\begin{array}{c}\text { Constant } \\
\text { Term }\end{array}$ & $\begin{array}{r}\text { Total } \\
\text { Investment } \\
\end{array}$ & $\begin{array}{r}\text { Public } \\
\text { Investment }\end{array}$ & $\begin{array}{r}\text { Private } \\
\text { Investment }\end{array}$ & DU82 & DU83 & DU86 & $R^{2}$ & $D W$ & $F$ & $\begin{array}{r}\mathrm{X}_{(1)^{2}} \\
\mathrm{SC}_{\mathrm{LM}} \\
\end{array}$ \\
\hline-0.22 & - & 0.53 & 1.82 & - & - & - & 0.58 & 1.62 & 12.30 & - \\
\hline$(-3.90)$ & - & (1.71) & $(3.81)$ & - & - & - & & & & \\
\hline-0.08 & - & 0.77 & 0.68 & -0.07 & -0.08 & -0.06 & 0.87 & 1.31 & 20.2 & 2.98 \\
\hline$(-2.0)$ & - & (3.87) & (1.90) & $(-4.14)$ & $(-3.31)$ & $(-4.04)$ & & & & \\
\hline-0.15 & 0.98 & - & - & - & - & - & 0.49 & 1.24 & 18.00 & 3.43 \\
\hline$(-3.25)$ & $(4.24)$ & - & - & - & - & - & & & & \\
\hline-0.09 & 0.74 & - & - & -0.07 & -0.08 & -0.06 & 0.87 & 1.34 & 26.80 & 2.61 \\
\hline$(-3.26)$ & (5.28) & - & - & $(-4.31)$ & $(-4.61)$ & $(-3.50)$ & & & & \\
\hline
\end{tabular}

Note. t-statistics in brackets.

As the aim of this work, however, is not to investigate the determinants of output growth, but to find estimates of the productivity in the public and private sectors of the economy, no other variables were introduced in the equation to try to improve the estimation. Further empirical evidence is given by estimating separately the relationship on the one hand between public investment and output growth, and, on the other hand, private investment, and output growth.

$$
\begin{gathered}
\Delta Y=\sigma_{1} I_{p b l} \\
\Delta Y=\sigma_{2} I_{p r v} \\
\text { or } \\
\dot{g}=\sigma_{1}\left(\frac{I_{p b l}}{Y}\right) \\
\dot{g}=\sigma_{2}\left(\frac{I_{p r v}}{Y}\right)
\end{gathered}
$$

The results estimating equations from (18) to (21) are shown in tables 3 and 4 . A constant term is included in all equations so that the marginal productivity of investment can be estimated. As in the previous estimations, dummy variables for the years when output is negative (1982, 1983 and 1986) are included (Note 8). 
Considering the estimated coefficients of public and private investment, it can be seen from Tables 3 and 4 that the coefficient of public investment is positive and statistically significant in both tables when the dummy variables are included. The estimated coefficients of private investment, although positive, lacks statistical significance except in the cases of equation (21) in table 4 when the dummy variables are excluded from the latter equation.

Table 3. Estimated marginal productivity of total, public and private investment

\begin{tabular}{cccccccccc}
\hline \multicolumn{10}{c}{$\begin{array}{c}\text { Equations (18) and (19) } \\
\mathbf{0}=\mathbf{g} /(\mathbf{I} / \mathbf{Y})\end{array}$} \\
\hline \multirow{2}{*}{ ConstantTerm } & $\begin{array}{c}\text { Public } \\
\text { Investment }\end{array}$ & $\begin{array}{c}\text { Private } \\
\text { Investment }\end{array}$ & DU82 & DU83 & DU86 & $\mathrm{R}^{2}$ & $D W$ & $F$ & $\mathrm{X}_{(1)}{ }^{2} \mathrm{SC}_{\mathrm{LM}}$ \\
\hline 2.10 & 0.46 & - & - & - & - & 0.10 & 1.22 & 2.14 & 3.31 \\
$(0.12)$ & $(1.46)$ & - & - & - & - & & & & \\
-5.21 & 0.75 & - & -57.8 & -77.9 & -53.3 & 0.93 & 1.52 & 37.7 & - \\
$(-0.41)$ & $(3.67)$ & - & $(-6.72)$ & $(-8.65)$ & $(.6 .97)$ & & & & \\
2.38 & - & 0.27 & - & - & - & 0.04 & 1.20 & 0.69 & 3.35 \\
$(0.27)$ & - & $(0.83)$ & - & - & - & & & & \\
-5.76 & - & 0.41 & -56.1 & -82.4 & -49.4 & 0.88 & 1.69 & 19.7 & - \\
$(-0.17)$ & - & $(1.43)$ & $(-5.01)$ & $(-6.70)$ & $(-5.03)$ & & & & \\
\hline
\end{tabular}

Note. t-statistics in brackets.

Table 4. Estimated marginal productivity of total, public and private investment

\begin{tabular}{|c|c|c|c|c|c|c|c|c|c|}
\hline \multicolumn{10}{|c|}{$\begin{array}{c}\text { Equations (20) and (21) } \\
\hat{\mathbf{o}}=\dot{\mathbf{g}} /(\mathbf{I} / \mathbf{Y}) \\
\end{array}$} \\
\hline ConstantTerm & $\begin{array}{r}\text { Public } \\
\text { Investment }\end{array}$ & $\begin{array}{c}\text { Private } \\
\text { Investment }\end{array}$ & DU82 & DU83 & DU86 & $\mathrm{R}^{2}$ & $D W$ & $F$ & $\mathrm{X}_{(1)}{ }^{2} \mathrm{SC}_{\mathrm{LM}}$ \\
\hline-0.05 & 1.23 & - & - & - & - & 0.45 & 1.81 & 6.89 & - \\
\hline$(-1.13)$ & $(2.22)$ & - & - & - & - & & & & \\
\hline-0.02 & 0.95 & - & -0.07 & -0.09 & -0.06 & 0.91 & 1.54 & 26.7 & - \\
\hline$(-0.77)$ & $(3.36)$ & - & $(-4.92)$ & $(-6.22)$ & $(-4.91)$ & & & & \\
\hline-0.21 & - & 2.09 & - & - & - & 0.51 & 1.6 & 20 & 0.78 \\
\hline$(-3.67)$ & - & $(4.43)$ & - & - & - & & & & \\
\hline 0.03 & - & 0.17 & -0.07 & -0.1 & -0.06 & 0.82 & 1.68 & 12.9 & - \\
\hline$(0.42)$ & - & $(+0.3)$ & $(-0.351)$ & $(-4.71)$ & $(-3.53)$ & & & & \\
\hline
\end{tabular}

Note. t-statistics in brackets.

\subsection{Incremental-Capital-Output Ratio Results (1970-1990)}

Table 5 shows the calculated annual ICOR coefficients for total, public and private investment, their period averages, and the calculated average productivities. It is interesting to notice the decrease in the estimated productivity values from the 1970-1981 period to the debt crisis period 1982-1990. It also can be seen that the estimated productivity of public investment does not seem either negative or lower than the productivity of private investment. The estimation results show higher productivity values for public investment than for private investment. The estimated productivity of public investment lies within the $0.617<\hat{o}_{1}<2.325$ range for the 1970 -1990 sub-period, and the estimated productivity values of private investment are within the range $0.328<\hat{\mathrm{o}}_{2}<$ 0.714 .

Table 5. Incremental capital-output ratio*

\begin{tabular}{cccc}
\hline Year & $(\mathrm{I} / \mathrm{Y}) /(\Delta \mathrm{Y} / \mathrm{Y})$ & $(\mathrm{Ipbl} / \mathrm{Y}) /(\Delta \mathrm{Y} / \mathrm{Y})$ & $(\mathrm{Iprv} / \mathrm{Y}) /(\Delta \mathrm{Y} / \mathrm{Y})$ \\
\hline $\mathbf{1 9 7 0}$ & 3.08 & 1.02 & 2.07 \\
$\mathbf{1 9 7 1}$ & 4.69 & 1.21 & 3.48 \\
$\mathbf{1 9 7 2}$ & 2.49 & 0.80 & 1.69 \\
$\mathbf{1 9 7 3}$ & 2.66 & 1.04 & 1.62 \\
$\mathbf{1 9 7 4}$ & 3.64 & 1.35 & 2.28 \\
\hline
\end{tabular}




\begin{tabular}{cccc}
\hline $\mathbf{1 9 7 5}$ & 4.08 & 1.69 & 2.39 \\
$\mathbf{1 9 7 6}$ & 5.15 & 1.96 & 2.39 \\
$\mathbf{1 9 7 7}$ & 5.66 & 2.16 & 3.51 \\
$\mathbf{1 9 7 8}$ & 2.64 & 1.16 & 1.48 \\
$\mathbf{1 9 7 9}$ & 2.63 & 1.12 & 1.52 \\
$\mathbf{1 9 8 0}$ & 3.05 & 1.31 & 1.74 \\
$\mathbf{1 9 8 1}$ & 3.44 & 1.56 & 1.88 \\
$\mathbf{1 9 8 2}$ & -38.68 & -17.11 & -21.57 \\
$\mathbf{1 9 8 3}$ & -2.83 & -1.12 & -1.71 \\
$\mathbf{1 9 8 4}$ & 4.58 & 1.77 & 2.81 \\
$\mathbf{1 9 8 5}$ & 6.31 & 2.24 & 4.07 \\
$\mathbf{1 9 8 6}$ & -4.23 & -1.49 & -2.74 \\
$\mathbf{1 9 8 7}$ & 8.61 & 2.65 & 5.96 \\
$\mathbf{1 9 8 8}$ & 11.04 & 3.05 & 7.99 \\
$\mathbf{1 9 8 9}$ & 5.57 & 1.47 & 4.11 \\
$\mathbf{1 9 9 0}$ & 4.84 & 1.25 & 3.59 \\
\hline & & Period Averages & 1.36 \\
\hline $\mathbf{1 9 7 0 - 1 9 9 0}$ & 1.83 & 0.43 & 3.20 \\
$\mathbf{1 9 7 0 - 1 9 9 0 * *}$ & 4.95 & 1.69 & 2.36 \\
$\mathbf{1 9 7 0 - 1 9 8 1}$ & 3.90 & 1.49 & 4.75 \\
$\mathbf{1 9 8 2 - 1 9 9 0 * *}$ & 6.82 & 2.07 & 0.735 \\
\hline & & & 3.048 \\
\hline $\mathbf{1 9 7 0 - 1 9 9 0}$ & 0.546 & 2.325 & 0.423 \\
$\mathbf{1 9 7 0 - 1 9 9 0 * *}$ & 0.214 & 0.591 & 0.120 \\
\hline $\mathbf{1 9 8 2 - 1 9 9 0} * * *$ & 0.277 & 0.735 & 0.483 \\
\hline
\end{tabular}

Source: World Development Indicators, World Bank

Note. $(*)$ ICORs $=(\mathrm{I} / \mathrm{Y}) /(\Delta \mathrm{Y} / \mathrm{Y})$

(**) It excludes 1982, 1983 and 1986, during which the rate of growth of output was negative.

\subsection{Econometric Results (1990-2019)}

A constant term is included in all equations so that the marginal productivity of investment can be estimated. As in the previous estimations, dummy variables for the years when output is negative (1995, 2001, 2002 and 2009) are included.

Table 6 shows the results of estimating equations (10) and (14) for the 1990-2019 sub-period. At table 6, when $\sigma \Lambda=\Delta \mathrm{Y} / \mathrm{I}$, a positive estimated of public investment $(\sigma \Lambda 1=0.50)$ and statistically significant $(\mathrm{t}=15.2)$ are obtained, while the estimated productivity of private investment is negative $(\sigma \Lambda 2=2.84)$ and statistically significant $(t=2.27)$. However, taking these results also at their face value, they are equal to those obtained by khan and Reinhart (1990) in the sense that a negative productivity would be relate to the private investment, but not to private investment.

Table 6. Estimated marginal productivity of total, public and private investment

\begin{tabular}{|c|c|c|c|c|c|c|c|c|c|}
\hline \multicolumn{10}{|c|}{$\begin{array}{c}\text { Equations (10) and (14) } \\
\qquad \hat{o}=\Delta \mathrm{Y} / \mathrm{I}\end{array}$} \\
\hline $\begin{array}{c}\text { Constant } \\
\text { Term }\end{array}$ & $\begin{array}{c}\text { Total } \\
\text { Investment }\end{array}$ & $\begin{array}{r}\text { Public } \\
\text { Investment }\end{array}$ & $\begin{array}{r}\text { Private } \\
\text { Investment }\end{array}$ & DU90 & DU93 & DU94 & $\mathrm{R}^{2}$ & $D W$ & $F$ \\
\hline 8.48 & - & 0.46 & 0.08 & - & - & - & 0.94 & 1 & 249 \\
\hline 18.57 & - & 9.34 & 2.84 & - & - & - & & & \\
\hline 8.27 & - & 0.5 & 2.84 & -0.07 & -0.14 & -0.14 & 0.98 & 0.77 & \\
\hline 33.29 & - & 15.2 & 2.27 & -2.97 & -11.3 & -17.31 & & & \\
\hline 8.11 & 0.56 & - & - & - & - & - & 0.9 & 1.3 & 258.28 \\
\hline 14.39 & 14.69 & - & - & - & - & - & & & \\
\hline 8.53 & 0.53 & - & - & - & & & 0.95 & 0.71 & 184.6 \\
\hline 16.06 & 14.78 & - & - & - & & & & & \\
\hline
\end{tabular}


The results estimating equations from (18) to (21) are shown in table 7. As before, a constant term is included in all equations so that the marginal productivity of investment might be estimated. As in the previous estimations, dummy variables for the years when output is negative $(1995,2001,2002$ and 2009) are included.

Table 7. Estimated marginal productivity of total, public and private investment

\begin{tabular}{|c|c|c|c|c|c|c|c|c|}
\hline \multicolumn{9}{|c|}{$\begin{array}{c}\text { Equations (18) to (21) } \\
\hat{\boldsymbol{o}}=\mathrm{g} /(\mathbf{I} / \mathbf{Y}) \\
\end{array}$} \\
\hline ConstantTerm & Total Investment & $\begin{array}{r}\text { Public } \\
\text { Investment }\end{array}$ & $\begin{array}{r}\text { Private } \\
\text { Investment }\end{array}$ & DUOO & DUO9 & $\mathrm{R}^{2}$ & $D W$ & $F$ \\
\hline 2.22 & 0.31 & - & - & -2.98 & -5.26 & 0.83 & 1.67 & 42.8 \\
\hline$(9.11)^{*}$ & $(8.85)^{*}$ & - & - & $(-2.34)^{*}$ & $(-4.04)^{*}$ & - & - & - \\
\hline 2.09 & 0.35 & - & - & - & - & 0.69 & 1.9 & 60.9 \\
\hline$(6.79)^{*}$ & $(0.80)^{*}$ & - & - & - & - & - & - & - \\
\hline 2.42 & - & 0.03 & 0.25 & -3.24 & -4.86 & 0.83 & 1.81 & 30.44 \\
\hline$(8.27)$ & - & $(1.78)^{*}$ & $(8.44)^{*}$ & $(-2.38)^{*}$ & $(-3.56)$ & - & - & - \\
\hline 2.02 & - & 0.04 & 0.28 & - & - & 0.7 & 1.97 & 30.5 \\
\hline$(6.44)^{*}$ & - & $(1.74)^{*}$ & $(7.68)$ & - & - & - & - & - \\
\hline
\end{tabular}

Note. t-statistics in brackets.

It can be seen from Table 7 that the coefficients of public investment and private investment alike are positive and statistically significant when the dummy variables are included.

\subsection{Incremental Capital-Output Ratio Results (1990-2019)}

According to Tables 8 and 9, the estimated productivity of public investment does not seem either negative or lower than the productivity of private investment. The estimation results show higher productivity values for public investment than for private investment. The estimated productivity of public investment lies within the $0.617<\hat{o} 1<2.325$ range for the $1990-2019$ sub-period, and the estimated productivity values of private investment are within the range $0.328<\hat{o} 2<0.714$.

Table 8. Incremental capital-output ratio*

\begin{tabular}{cccc}
\hline Year & $(\mathrm{I} / \mathrm{Y}) /(\Delta \mathrm{Y} / \mathrm{Y})$ & $(\mathrm{Ipbl} / \mathrm{Y}) /(\Delta \mathrm{Y} / \mathrm{Y})$ & $(\mathrm{Iprv} / \mathrm{Y}) /(\Delta \mathrm{Y} / \mathrm{Y})$ \\
\hline $\mathbf{1 9 9 0}$ & 3.47 & 0.83 & 2.64 \\
$\mathbf{1 9 9 1}$ & 4.44 & 0.97 & 3.48 \\
$\mathbf{1 9 9 2}$ & 5.54 & 1.07 & 4.47 \\
$\mathbf{1 9 9 3}$ & 10.74 & 1.57 & 9.17 \\
$\mathbf{1 9 9 4}$ & 4.39 & 0.80 & 3.58 \\
$\mathbf{1 9 9 5}$ & -2.60 & -0.47 & -2.13 \\
$\mathbf{1 9 9 6}$ & 2.72 & 0.35 & 2.37 \\
$\mathbf{1 9 9 7}$ & 2.90 & 0.36 & 2.54 \\
$\mathbf{1 9 9 8}$ & 4.08 & 0.43 & 3.66 \\
$\mathbf{1 9 9 9}$ & 7.67 & 0.87 & 6.80 \\
$\mathbf{2 0 0 0}$ & 4.35 & 0.59 & 3.75 \\
$\mathbf{2 0 0 1}$ & -49.29 & -7.32 & -41.98 \\
$\mathbf{2 0 0 2}$ & -483.62 & -91.47 & -392.15 \\
$\mathbf{2 0 0 3}$ & 13.67 & 2.87 & 10.81 \\
$\mathbf{2 0 0 4}$ & 5.22 & 1.08 & 4.14 \\
$\mathbf{2 0 0 5}$ & 8.97 & 1.95 & 7.03 \\
$\mathbf{2 0 0 6}$ & 4.79 & 1.02 & 3.78 \\
$\mathbf{2 0 0 7}$ & 9.58 & 2.01 & 7.57 \\
$\mathbf{2 0 0 8}$ & 20.26 & 4.89 & 15.37 \\
$\mathbf{2 0 0 9}$ & -4.19 & -1.13 & -3.06 \\
$\mathbf{2 0 1 0}$ & 4.22 & 1.10 & 3.12 \\
$\mathbf{2 0 1 1}$ & 6.08 & 1.40 & 4.68 \\
$\mathbf{2 0 1 2}$ & 6.27 & 1.26 & 5.02 \\
\hline
\end{tabular}




\begin{tabular}{|c|c|c|c|}
\hline 2013 & 15.69 & 3.26 & 12.44 \\
\hline 2014 & 7.37 & 1.45 & 5.92 \\
\hline 2015 & 6.81 & 1.10 & 5.71 \\
\hline 2016 & 8.67 & 1.35 & 7.32 \\
\hline 2017 & 10.45 & 1.46 & 9.00 \\
\hline 2018 & 10.04 & 1.38 & 8.66 \\
\hline 2019 & -379.02 & -47.82 & -331.20 \\
\hline \multicolumn{4}{|c|}{ Period Averages } \\
\hline 1990-2019 & -24.34 & -3.76 & -617.50 \\
\hline $1990-2019 * *$ & 3.42 & 8.847 & 7.436 \\
\hline 1990-2000 & 4.336 & 0.695 & 2.756 \\
\hline 2001-2019** & 7.536 & 1.837 & 7.369 \\
\hline \multicolumn{4}{|c|}{$\widehat{o}=I / I C O R$} \\
\hline $1990-2019$ & -23.34 & -2.76 & -616.5 \\
\hline $2019-2019 * *$ & 0.92 & 0.113 & 0.134 \\
\hline $1990-2000$ & 0.23 & 1.438 & 0.362 \\
\hline 2001-2019** & 0.132 & 0.544 & 0.135 \\
\hline \multicolumn{4}{|c|}{ Source: World Development Indicators, World Bank } \\
\hline
\end{tabular}

Note. $\left({ }^{*}\right) \mathrm{ICORs}=(\mathrm{I} / \mathrm{Y}) /(\Delta \mathrm{Y} / \mathrm{Y})$

(**) It excludes 1982, 1983 and 1986, during which the rate of growth of output was negative.

\section{Conclusion and Discussion}

During the 1970-2019 period the financing of Mexico's growth and development depended on both domestic and foreign sources. In fact, the performance of the economy has been associated with the availability of external financing, let alone the need of to rise and induce private investment to productive fields. The convergence of a state-led economic model exhausted and the relative unavailability of external financing after the debt crisis began in 1982 led the Mexican Economy to increase its reliance on internal sources of finance. So that, with the purpose of increasing domestic financing and improve the allocative efficiency of resources, the financial sector was liberalised in path of main hypothesis of liberalisation models.

With that underlying rationale, this research picked to disentangle real facts from the expected benefits the multilateral financial institutions and governments preached through a specific kind of hypothesis, that claiming the superiority of private investment over the incumbent governmental expenditure and that the best option for less developing countries must be to allow market forces to overhaul their repressed financial system. In the light of it, resources allocated through direct policy intervention in financial markets are inefficiently used, and hamper, rather than help, the process of economic growth, were told. Therefore, such hypothesis implies that public investment, which was allocated mainly on economic planning/non-market-based criteria, and using direct instruments of credit control, is less productive than private investment.

According to the empirical evidence concerning the productivity of public and private investment, there is no statistical evidence that public is less productive than private investment. That data also shows a decline in the levels of productivity investment, both public and private, after the debt crisis 1982 in the first sub-period (1970-1990). The decline in productivity coincides with the fall in the levels of investment after 1982, especially of public investment.

Investment in developing countries, public and private, is related to growth and development, and the macroeconomic conditions and policies through which investment and growth can flourish should have a top policy (Shaalan, 1990). When attempted to discern the allegedly superiority of the private investment over the public investment invoked by the theory of financial liberalisation, the empirical evidence from the Mexican economy does not support the hypothesis that the public investment being lower than private investment, or that public investment is unproductive.

After more than three decades, the euphoria which accompanied Mexico's liberalisation policies have begun to wane. Nevertheless, such policies seem to have elicited a positive response from the private and foreign sectors in the country's economic future at the time. Despite so vital confidence to investment, however, the government must cope with the rising of the private saving to significantly enhance loanable funds in the banking system, but above all, with the implementation of an effective inducement, first to invest and second to channelise resources to the agricultural and industrial sectors, without having any intervention whatsoever in the financial system. 
Likewise, for the same reason it faces the challenge to ensure foreign long-term direct investment and not speculative portfolio investment which can be highly volatile.

\section{Acknowledgements}

This work was funded by the Programa de Apoyo a Proyectos de Investigación e Innovación Tecnológica (PAPIIT), Dirección General de Asuntos del Personal Académico (DGAPA), National University of Mexico (UNAM) through the Project IN311620 code.

\section{References}

Aldred, J. (2010). The Skeptical Economist: Revealing the Ethics inside Economics. United Kingdom: Earthscan. https://doi.org/10.4324/9781849773263

Balassa, B. (1990). The Effects of Interest Rates on Savings in Developing Countries. Policy Choices for the 1990s. London: Palgrave Macmillan. https://doi.org/10.1007/978-1-349-13033-7_8

Collier, P., \& Mayer C. (1989) The assessment: Financial Liberalization, Financial Systems, and Economic Growth. Oxford Review of Economic Policy, 5(4). https://doi.org/10.1093/oxrep/5.4.1

Fitzgerald, E., Pyatt, G., \& Malik, S. (1992). Private Sector Investment and Savings Behaviour: The Policy Implications of Capital Account (with comments). The Pakistan Development Review. https://doi.org/10.30541/v31i4Ipp.491-510

Haskel, J., \& Westlake, S. (2018) Capitalism without Capital: The rise of the intangible economy. Princeton University, and Oxford University Press. https://doi.org/10.3326/pse.44.1.5

Ize, A., \& Ortiz, G. (1987). Fiscal rigidities, public debt and capital flight. IMF Staff Papers, 1987(001), A004. https://doi.org/10.2307/3867137

Khan, \& Reinhart. (1989). Private investment and economic growth in developing countries. International Monetary Fund No.060. https://doi.org/10.5089/9781451965247.001

Leibenstein, H. (1966). Incremental Capital-Ratios and Growth Rates in the Short Run. Review of Economics and Statistics, 18(1), 20-27. https://doi.org/10.2307/1924854

Mukherjee, C. et. al. (1998) Econometric and Data Analysis for Developing Countries. Routledge, London. https://doi.org/10.4324/9781315003580

Nadiri, M. I. (1970). Some Approaches to the Measurement of Total Factor Productivity: A Survey. Journal of Economic Literature, 8(4), 1137-1177. Retrieved from http://www.jstor.org/stable/2720722

Newlyn, W. T., Avramides, U., Brothwell, J. F., Kessel, N., \& Rao, S. K. (1977). The financing of economic development. https://doi.org/10.2307/2232070

Sarmad, K. (1990). Public and Private Investment and Economic Growth. Working Paper No.34, Institute of Social Studies.

Shaalan, A. S. (1990) The Impact of Macroeconomic Policies on Investment. Investment Policies in the Arab Countries: IMF e-library. https://doi.org/10.5089/9781557751409.071

Shone, R. (1981) Applications in Intermediate Microeconomics. Martin Robertson, United Kingdom: Oxford.

Tanzi, V. (1976). Fiscal Policy, Keynesian Economics and the Mobilization of Savings in Developing Countries. in World Development, 4, 10-11. https://doi.org/10.1016/0305-750X(76)90080-2

Thirlwall, A. P. (1989). Growth and Development with Special Reference to Developing Economies. Macmillan. https://doi.org/10.1007/978-1-349-06713-8

Wall, J. W. (1990). Efficiency of Public Investment: Lessons from World Bank Experience. Investment Policies in the Arab Countries IMF e-library. https://doi.org/10.5089/9781557751409.071

Warman, F., \& Thirlwall, A. P. (1993) Interest rates, saving, investment and growth in Mexico 1960-90: Tests of the financial liberalisation hypothesis. The Journal of Development Studies, 30(3). https://doi.org/10.1080/00220389408422330

World Bank. (1989). World Development Report 1989: Financial Systems and Development. New York: Oxford University Press. Retrieved from https://openknowledge.worldbank.org/handle/10986/5972

World Bank. (2021). World Development Indicators. Retrieved from https://databank.worldbank.org/source/world-development-indicators 


\section{Notes}

Note 1 . In the present analysis, the actual ICOR is considered. Its calculation formula is: $\Delta \mathrm{K} / \Delta \mathrm{Y}=(\mathrm{I} / \mathrm{Y}) /$ $(\Delta \mathrm{Y} / \mathrm{Y})$.

Note 2. Thus, it is not a fortuitous fact that the World Bank has used such relationship to calculate financing needs for less developed countries.

Note 3. Even though both of such calculations are useful, it is pertinent to highlight the advantage of the marginal productivity indicator to communicate as the comparatively performance of different kind of investment as the related public policies steaming of.

Note 4. The average productivity of capital is defined as the output-input ratio for each level of output and the corresponding level of input $(\mathrm{K})$, whereas the marginal productivity of capital is the addition to total product attributable to the addition of one unit of capital.

Note 5. The process of including and excluding dummy variables in the econometric exercise done reflects a sort of sensitivity of the estimated coefficients.

Note 6. This lack of statistical significance is perhaps due to the presence of multicollinearity in the regression.

Note 7. Tables 1 and 2 include the results obtained in such a way to show the sensitivity of the estimated coefficients to the inclusion or exclusion of dummy variables.

Note 8. Except in the case of equation (21), where F statistics does not improve.

\section{Copyrights}

Copyright for this article is retained by the author(s), with first publication rights granted to the journal.

This is an open-access article distributed under the terms and conditions of the Creative Commons Attribution license (http://creativecommons.org/licenses/by/4.0/). 